\title{
Scanning Electron Microscopy, Video-image Analysis, and Confocal Imaging of Changes Occuring during Peach Fruit Abscission
}

\author{
Uday K. Tirlapur ${ }^{1}$, Guglielmo Costa ${ }^{2}$, Carlo Malossini, and Giannina Vizzotto \\ Dipartimento di Produzione Vegetale e Tecnologie Agrarie, Universitá di Udine, Via delle Scienze 208, \\ I-33100 Udine, Italy \\ Mauro Cresti \\ Dipartimento di Biologia Ambientale, Universitá di Siena, Via P.A. Mattioli 4, I-53100 Siena, Italy
}

Additional index words. $\mathrm{Ca}^{2+}$, Prunus persica, AZ3, fruit drop

\begin{abstract}
Redhaven' peach (Prunus persica L. Batsch) fruit abscission has been investigated using scanning electron microscopy, computer-assisted video-image analysis, and confocal laser scanning microscopy in conjunction with chlorotetracycline and ethidium bromide as fluorescent probes for membrane $\mathrm{Ca}^{2+}$ and nuclear DNA. This enabled us to document the morphological changes of the cells, distribution patterns of membrane $\mathrm{Ca}^{2+}$ in the constituent cells of the abscission zone, and the nuclear morphology with accompanying changes in nuclear DNA. The digitized images of CTCfluorescence emissions revealed that the membrane $\mathrm{Ca}^{2+}$ levels in the pre-abscission zone (control) is uniform and similar to that present in the cells of the spongy proximal region of the peduncle and that of the fruit parenchyma. However, with the induction of abscission, 2 days after embryoctomy, there was a significant increase in membrane $\mathrm{Ca}^{2+}$ in the cells of the abscission zone compared to the neighboring cells of the fruit and the peduncle. Thereafter, with the gradual separation of the cells and the concomitant vacuolation, the membrane $\mathrm{Ca}^{2+}$ level decreased substantially. Confocal imaging of $\mathrm{EB}$ labeled cells of the abscission zone before induction invariably revealed a well-organized nucleus. However, during cell separation, significant changes in the cellular and nuclear morphology occured, including 1) rounding of cells, 2) reduction in the nuclear volume, and 3 ) concomitant fragmentation of nuclear DNA. The possible role of $\mathrm{Ca}^{2+}$ during the process of peach fruit abscission and nuclear DNA fragmentation leading to cell death is discussed. Chemical names used: chlorotetracycline (CTC), ethidium bromide (EB).
\end{abstract}

Studies on fruit abscission in peaches (Bukovac, 197 1; Daniel1 and Wilkinson, 1972; Dermen and Stewart, 1973; Martin and Nishijima, 1972; Jerie, 1976; Schneider, 1977) have mainly dealt with chemically induced fruit drop (Arnold et al., 1981; Nelson et al., 1984). Following the detailed anatomical studies of Nelson et al. (1984), Rascio et al. (1985) investigated some of the ultrastructural and biochemical aspects related to peach fruit abscission.

Recently, $\mathrm{Ca}^{2+}$ has been considered as an important intracellular messenger in plants (Poovaiah, 1988) and has been implicated in senescence-related biochemical processes. Calcium is essential for the maintenance of structural integrity of biomembranes and cell walls (Hanson, 1983; Jones and Lunt, 1967; Marinos, 1962; Paliyath et al., 1984; Poovaiah and Leopold, 1973; Poovaiah and Rasmussen, 1973).

Stösser et al. (1969a, 1969b) histochemically investigated abscission layer formation in Prunus cerasus L. These authors reported that the cells of the abscission layer contained less total polysaccharides than the adjacent cells. They also found that the pectins were degraded and that cellulose associated with the walls was broken down, resulting in cell separation. Interestingly, they also detected a decrease in $\mathrm{Ca}$ and $\mathrm{Mg}$ in the cell walls during

Received for publication 6 July 1994. Accepted for publication 7 Nov. 1994. We thank Claudio Milanesi for his technical assistance. The contract grant from the Univ. of Udine and the visiting fellowship of the Univ. of Siena to U.K.T is gratefully acknowledged. This research was supported by the grant from MIRAAF "Peach fruit chemical thinning" to G.C. The cost of publishing this paper was defrayed in part by the payment of page charges. Under postal regulations, this paper therefore must be hereby marked advertisement solely to indicate this fact. ${ }^{1}$ Also with Dipartimento di Biologia Ambientale, Universita di Siena, Via P.A. Mattioli 4, I-53100 Siena, Italy. Present address: Dept. of Biology, Univ. of Utah, 201 Biology Building, Salt Lake City, UT 84112.

${ }^{2}$ To whom reprint requests should be addressed. abscission. A striking observation made by these authors was the relatively lower ${ }^{45} \mathrm{Ca}$ binding capacity of the cells of the abscission layer than that of the distal or proximal layer of cells. In a subsequent detailed histoautoradiographic study Stösser (1969a, $1969 \mathrm{~b}$ ) reported that, in sweet and sour cherries, ${ }^{45} \mathrm{Ca}$ was uniformly distributed in the abscission zone and in the tissue distal and proximal to it. Furthermore, the level of ${ }^{45} \mathrm{Ca}$ in the abscission zone decreased and was lost from these cells after initiation of abscission.

It is known from earlier studies (Nelson et al., 1984; Rascio et al., 1985) that fruit drop in peaches occurs by the activation of three abscission zones (AZs), namely, AZ1 (present between the peduncle and the twig), AZ2 (situated between the flower receptacle and the peduncle), and AZ3 (situated between the fruit and the receptacle). However, there is no information pertaining to the changes in $\mathrm{Ca}^{2+}$ levels or in the nuclear DNA of the constituent cells of the AZ3 zone. In the present study, we have investigated structural aspects of the AZ3 cells, the spatial and temporal changes in membrane $\mathrm{Ca}^{2+}$ (Wolniak et al., 1980), and the changes in nuclear DNA in cells of the abscission zone in peach

\section{Materials and Methods}

Plant material and experimental treatments. All experiments were carried out on peaches from 5-year-old 'Redhaven' trees grown in the orchards of the Univ. of Udine (Italy) during May to June 1993. Abscission was experimentally induced in the fruits by embryoctomy at the end of stage I of fruit development (Connors, 1919). Embryoctomy was carried out as described by Rascio et al. (1985). Briefly, 6 to 10 fruit (with a transversal diameter of $37 \mathrm{~mm}$ ) were cut and the seeds were scooped out with a sterilized scalpel, 
after which the kinetics of fruit drop was monitored.

Scanning electron microscopy. Samples of $\approx 3 \mathrm{~mm}^{2}$ inclusive of the AZ3 zone were fixed in $3 \%$ glutaraldehyde prepared in $0.06 \mathrm{M}$ cacodylate buffer at $\mathrm{pH} 7.2$ for $30 \mathrm{~min}$ at room temperature, rinsed with the same buffer, and immediately dehydrated through ethanol series. For critical-point drying, ethyl alcohol was replaced by freon 113 and then by liquid $\mathrm{CO}$, which was brought to critical point in Balzers chamber. Subsequently, samples were coated with gold in Edwards sputter coater S 150 A and observed with Philips SEM 501 B. Black and white photographs were taken with Ilford PAN F ISO 50 film.

Labeling with fluorescent probes. Fresh sections or isolated
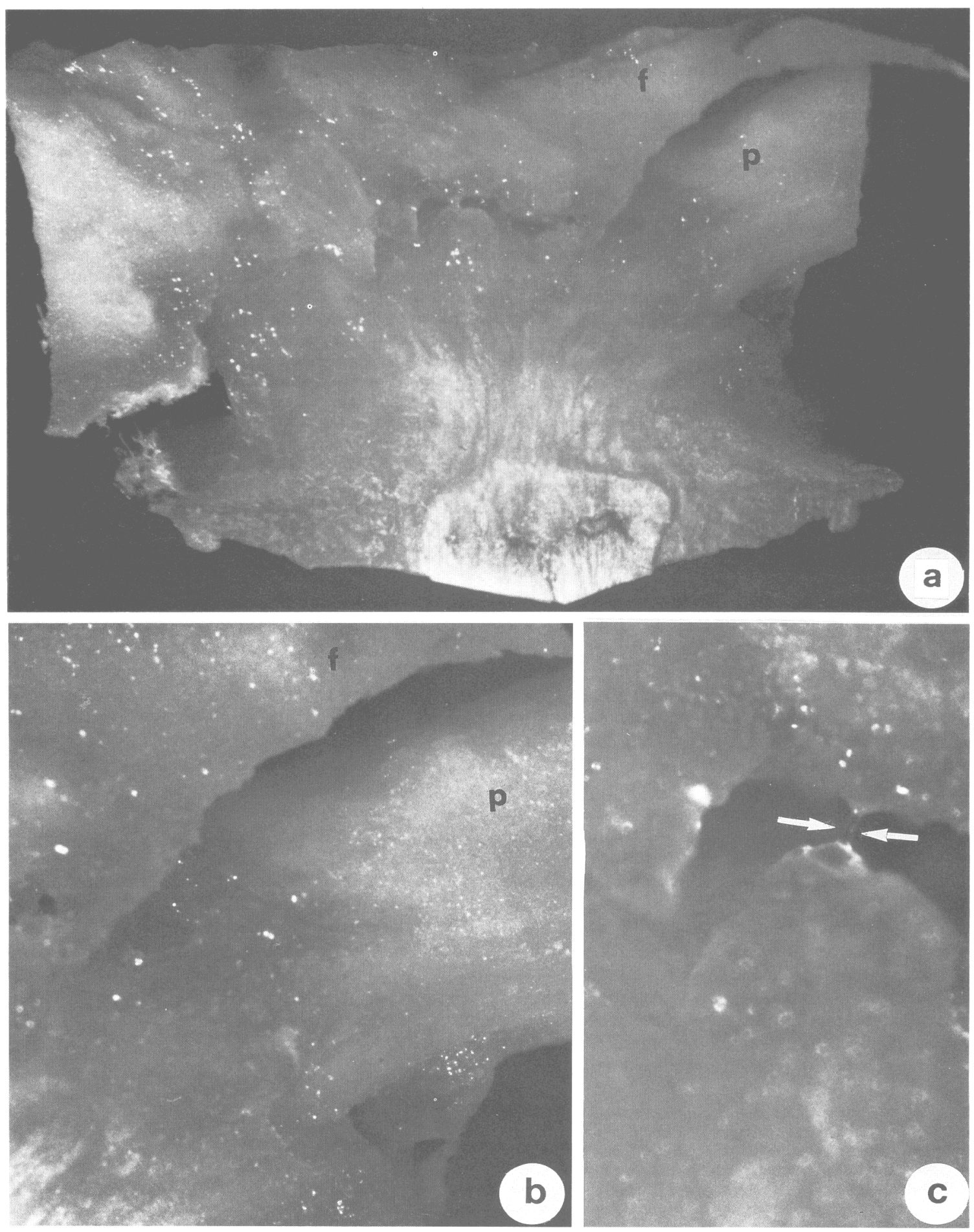

Fig. 1. (a) Vertical macroscopical view of the abscising region (after 4 day $\backslash$ of embryoctomy) between the peduncle (p) and the fruit (f). (b) Higher magnification of a part of the abscising region showing the differences in the texture of the tissue in the fruit (f) and the peduncle (p). (c) Close-up view of the mucilagenous secretion (arrows) present in the abscising region. 
cells of the abscission zone were labelled with $20 \mu \mathrm{M}$ CTC prepared in $4.4 \%$ glucose plus $2.5 \%$ mannitol for $5 \mathrm{~min}$, rinsed in the same solution without CTC, and examined. The control included posttreatment of CTC-labeled sections with $5 \mathrm{~mm}$ EGTA. For labeling of the nuclei, cells were initially fixed in $2.5 \%$ glutaraldehyde (in phosphate buffer, $\mathrm{pH}$ 7.4) for $15 \mathrm{~min}$ at room temperature, rinsed in the buffer, and incubated in $2 \mu \mathrm{m}$ ethidium bromide. Cells were then rinsed in three changes of the buffer for 5 min each and observed under a CLSM as described below.

Video recording and image analysis of CTC-fluorescence.
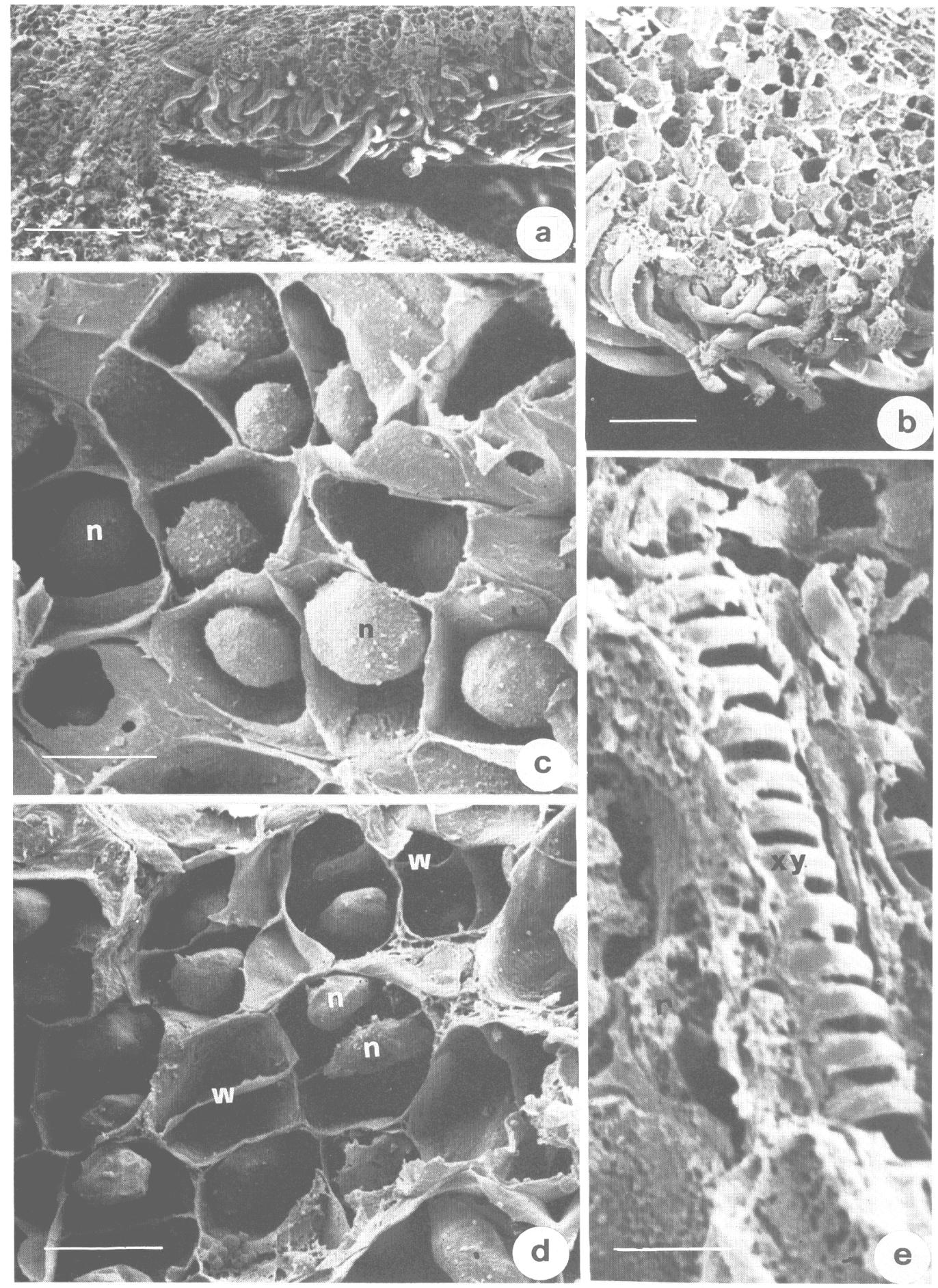

Fig. 2. (a) Scanning electron micrograph of the longitudinal profile of tissues of the abscission zone (AZ3). the fruit parenchyma and that of the peduncle. Scale bar $=130 \mu \mathrm{m}$. (b) Scanning electron micrograph of the spongy fruit parenchyma and the epidermal hair. Scale bar $=30 \mu \mathrm{m}$. (c) Scanning electron micrograph of the proximal band of spongy cells with large intracellular space $(n=$ nucleus, $w=$ cell wall). Scale bar $=30 \mu \mathrm{m}$. (d) Scanning electron micrograph of the surface view of the small distal band of cells adjoining the fruit parenchyma. Note the presence of relatively fewer intracellular spaces. Scale bar $=30 \mu \mathrm{m}$. (e) Longitudinal view of a intact xylem vessel (xy) present in the vascular strand of the control material. Scale bar $=60 \mu \mathrm{m}$. 
Cells loaded with CTC were examined with a Leitz Orthoplan epifluorescence microscope. Ultraviolet excitation was obtained from a 50-W mercury-vapor lamp and the dye was excited using a combined filter set: BP365 (excitation filter), FT395 (dichroic mirror), and LP397 (barrier filter). Fluorescence emanating from the cells was observed with either $20 \times / 0.50$ Pol or $40 \times / 0.75$ Pol Plan-Neofluar objectives combined with 1 Ox eyepieces. For image acquisition, fluorescence signals emanating from the sections were recorded with a black and white video camera (Sony DXC$101 / 101 \mathrm{P}$; at low light setting) mounted on the microscope tube (Tirlapur and Cresti, 1992; Tirlapur et al., 1992). Individual video images were subsequently transferred to the hard disk of the host computer.

For image analysis, images were retrieved from the hard disk and the hardware and software system supplied with the BioRad MRC 500 confocal laser scanning microscope were used to manipulate and enhance fluorescence microscope images. Digitation and pseudocolor representation (wherein variations in pixel intensity profiles are demonstrated using color coding from 0 to 255 gray values) of the images was done as described by Tirlapur and Cresti (1992).

Confocal laser scanning microscopy of EB-labeled cells. The nuclear EB fluorescence was excited using a GHS filter set interfaced with an Argon-ion laser scanner of a BioRad MRC 500 laser scan confocal microscope. A Nikon oil immersion objective (600x, PlanApo) was used for noninvasive optical sectioning with zoom setting at 3 and scan speed of $3 \mathrm{sec}$ per frame while at least nine frames were averaged with the kalman filter. The z-series images were acquired every 0.5 or $1.0 \mu \mathrm{m}$ spacing steps by the computer-controlled motor drive. A total of 15 or 30 optical images was collected and stored in the hard disk memory of the host computer for further image analysis. Photobleaching of EB fluorescence was minimized by scanning the samples during the acquisition of the images, and the laser intensity was attenuated by interfacing a variable neutral density filter into the illumination path.

Image analysis including pseudocolour representation was carried out using the standard software supplied with BioRad MRC 500 confocal laser scanning microscope (Bacon et al., 199 1; Tirlapur and Cresti, 1992; Tirlapur et al., 1992, 1993a, 1994b).

\section{Results}

Observation of the AZ3 zone 4 days following embryoctomy (Fig. $1 \mathrm{a}$ and b) reveals that these cells have an amorphous appearance unlike that of the neighboring cells of the fruit or the receptacle. Following separation of the cells, mucilagenous matrix (Fig. 1c) is often seen in the space separating the fruit and the receptacle.

Scanning electron microscopy. The scanning image (Fig. 2a) of thick median section of the AZ3 (before induction) and a part of the pedicel reveals the presence of proximal spongy region and a distal compact region. The outer surface of the fruit parenchyma (Fig. $2 b)$ is covered by numerous trichomes that are absent on the surface of the pedicel. The abscission zone constituently appears to be formed by two different set of bands of cells consisting of 8 to 10 rows. The proximal band of cells has a spongy appearance but with relatively more intercellular spaces (Fig. 2c) than distally located small cells that have very little intercellular spaces (Fig. $2 d)$. The zone also contains well-organized vascular bundles consisting of phloem and xylem elements (Fig. 2e) traversing between the receptacle and the fruit. In the spongy fruit parenchyma, some of the cells contain highly organized crystalline inclusions (Fig. 3a). The first morphological evidence of abscission by way of cell separation was apparent 4 days after embryoctomy (Fig. 3b). During this period, the vascular strands between the receptacle and the fruit were severed (Fig. 3c).

Video imaging of changes in CTC fluorescence in the AZ3 zone. In the longitudinal optical view, relatively high CTC fluorescence was observed in the central part of the vascular tissue between the
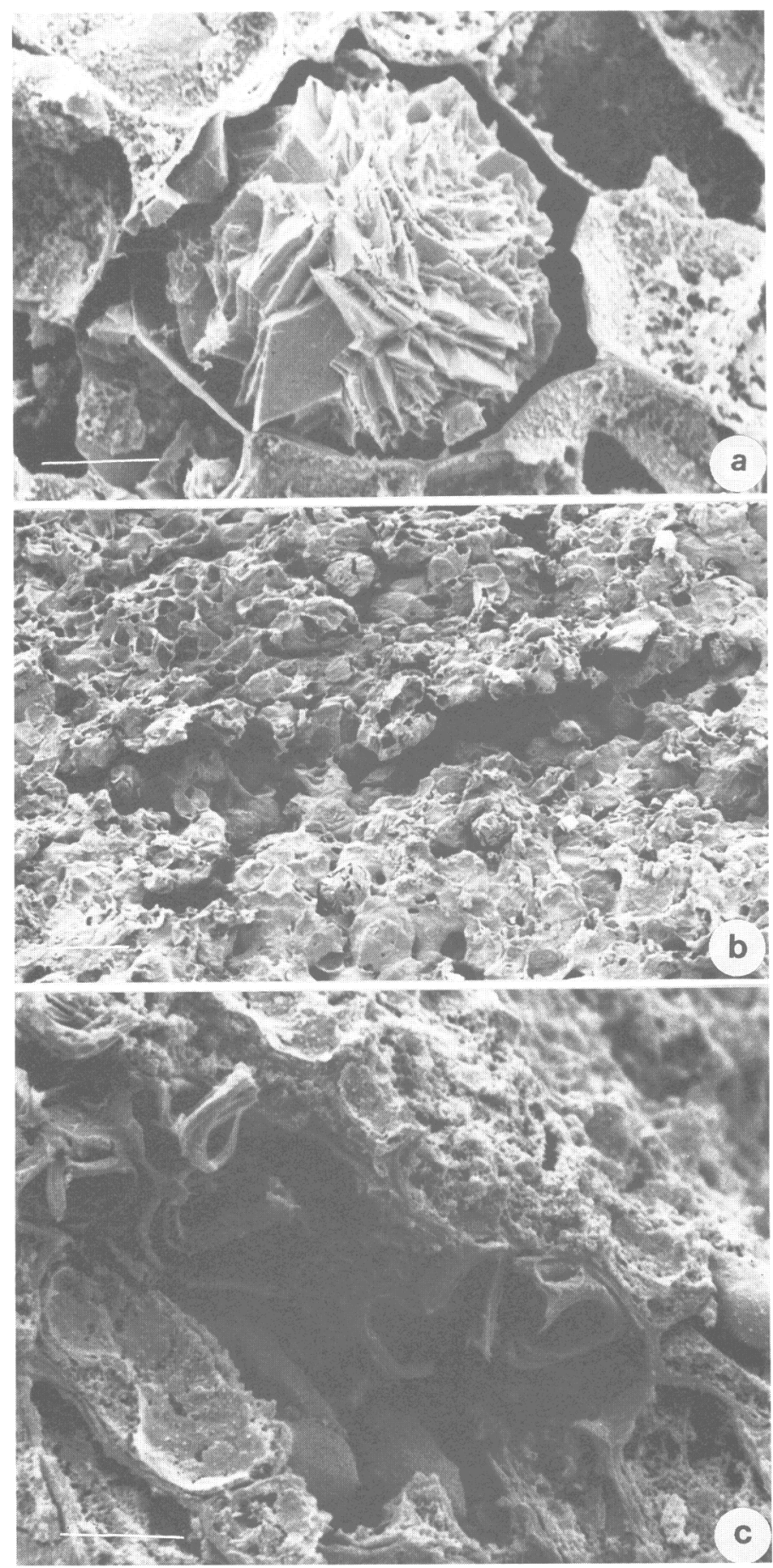

Fig. 3. (a) Scanning image of (a) a highly organized crystal (possibly calciumoxalate) in one of the fruit parenchyma cell. Scale bar $=7.5 \mu \mathrm{m}$. (b) Scanning electron micrograph of the abscised done with a few separated cells. Scale bar = $30 \mu \mathrm{m}$. (c) Scanning electron micrograph of the abscised zone in the area of the vascular strands. Note the separation of the xylem vessels. Scale bar $=30 \mu \mathrm{m}$. 
receptacle and the fruit, while in the pre-abscission AZ3 and in the tissue distal and proximal to the pre-abscission AZ3, CTC fluorescence was uniformly low (Fig. 4a). However, 2 days after embryoctomy, a significant increase in CTC fluorescence in the cells of AZ3 could be clearly visualized (Fig. 4b). A slight increase in the CTC fluorescence in the tissue distal and proximal to the AZ3 could be seen. Control samples posttreated with 5 mm EGTA did not reveal any fluorescence above the background level (data not shown).

With the progression of abscission, the cells began to separate and clusters of 20 to 30 club-shaped or spheroidal cells (Fig. 4c) could often be found in AZ3. The rounding of these cells was accompanied by the development of small vacuoles that gradually coalesced into one large vacuole (Fig. 4d). During the later stages of cell separation and rounding, CTC fluorescence in $>80 \%$ of the cells decreased, while there was an increase in the CTC fluorescence in the intercellular spaces (Fig. 4e).

Confocal laser scanning microscopy of nuclear DNA in abscising cells. The nuclei in the club-shaped abscising cells were generally found in the narrow end of the cell (Fig. 5a). With further vacuolation of this cell type, the originally spherical nuclear morphology was obliterated with a concomitant loss in the EB stainability (Fig. 5b). Similarly, the cells before separation contain a large nuclei showing significantly high EB stainability (Fig. 5c). Following cell separation and rounding (Fig. $5 \mathrm{~d}$ and e), which is accompanied by vacuolation, there is gradual change in nuclear morphology and a decrease in the EB stainability. Eventually, in highly vacuolated cells (Fig. $5 \mathrm{f}$ and $\mathrm{g}$ ) with peripherally regionalized cytoplasm, there is further decrease in nuclear EB stainability. The dead cells in the population are characterized by fragmentary remains of the nuclei that show weak EB fluorescence (Fig. 5h).

\section{Discussion}

The morphological features of the abscission region in peaches are in several ways comparable to those reported earlier by Rascio et al. (1985). They are distinguishable before activation and are thus consistent with the target-cells hypothesis proposed by Osborne (1979). The abscission zone consists of two discrete proximal and distal bands of cells, the former composed of large cells with numerous intercellular spaces and the latter with relativelv smaller cells with few intracellular spaces. This situation is analogous to
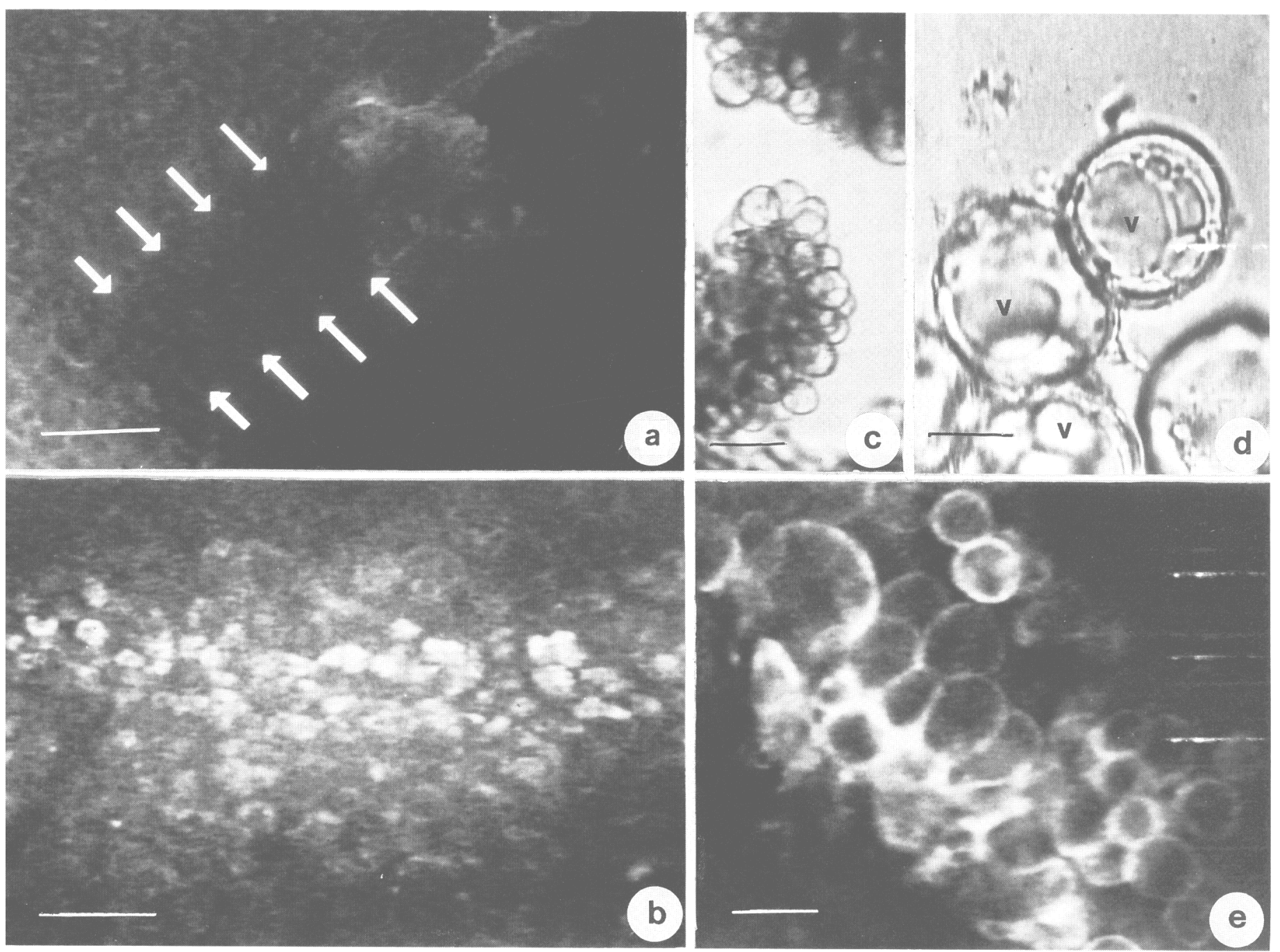

Fig. 4. (a) Video Image of the pre-abscission zone showing low level of CTC fluorescence. Scale bar $=120 \mu \mathrm{m}$. (b) Video image of the AZ3 showing the increase in the CTC fluorescence 2 days after embryoctomy. Scale bar $=90 \mu \mathrm{m}$. (c) Bright-field video image of cluster of abscised round cells 4 days after embryoctomy. Scale bar $=60 \mathrm{pm}$. (d) Higher magnification of abscised round cells showing the presence of large vacuole (v) 4 days after embryoctomy. Scale bar $=15 \mu \mathrm{m}$. (e) Video image of CTC fluorescence of the cluster of cells comparable to that shown in Fig 4c. Note the loss of cellular CTC fluorescence in most of these cells and the presence of high CTC fluorescence in the intracellular spaces. Scale bar $=30 \mu \mathrm{m}$. 

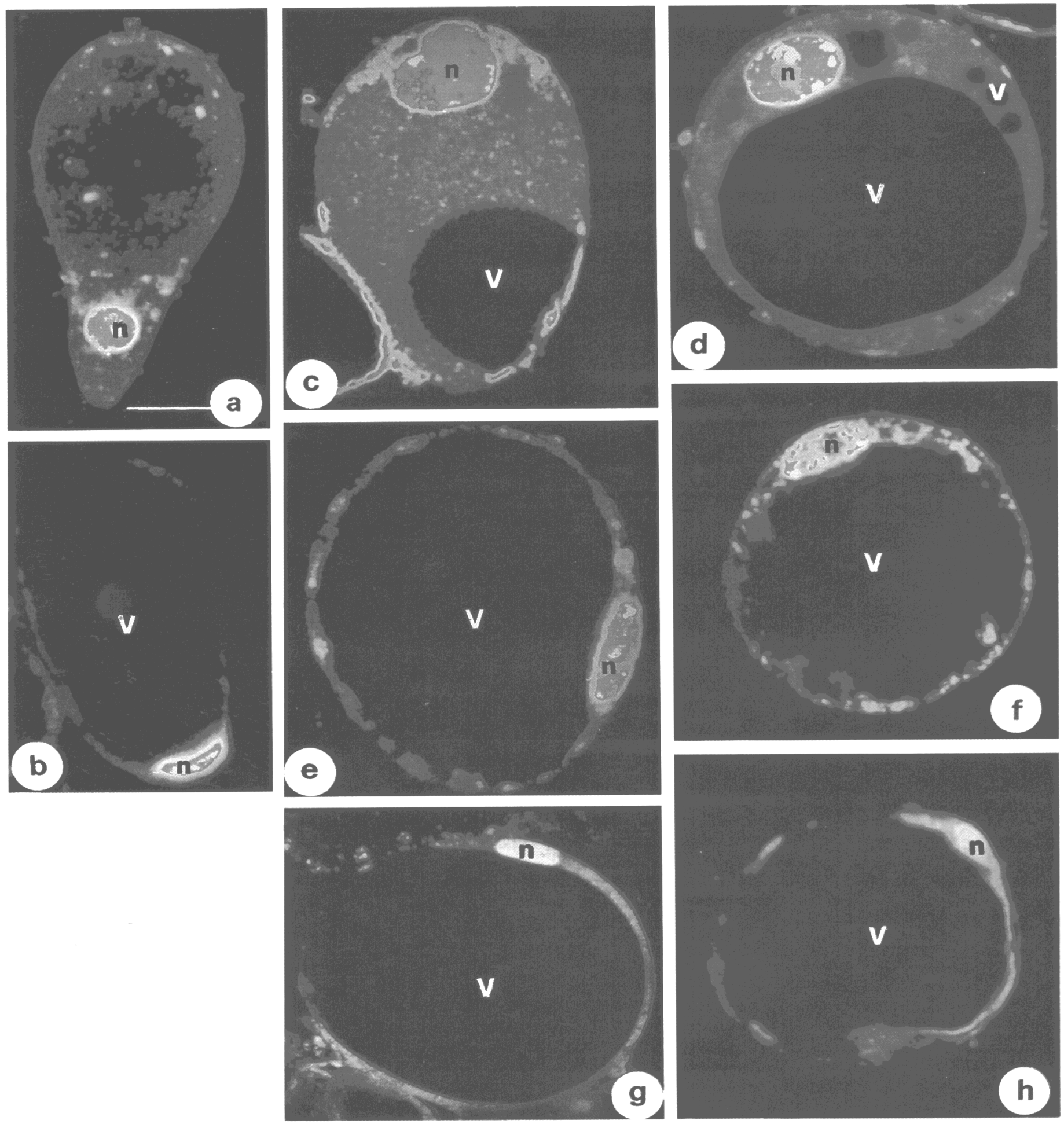

Fig. 5. Pseudocolor coded confocal images of EB-labeled cells of AZ3 zone The inset wedge represents pixel-intensity values between 0 to 255 . (a) Confocal image of a isolated club-shaped cell of the AZ3 with a spherical nuclei (n) at the base. Pseudocolor coded to show the intensity of EB fluorescence of nuclear DNA. Scale bar $=10 \mu \mathrm{m}$. (b) Confocal image a vacuolate club-shaped cell in the population of the AZ3 with obliterated nuclei (n). (c) Pseudocolor coded EB fluorescence image showing a large nuclei (n) in the unseparated cell of the AZ3 with distally located vacuole (v), (d-f) Pseudocolor coded confocal images of completely separated AZ3 cells which began to round-off. Note the increase in the size of the vacuole (v) and gradual change in the size, loss in the EB stainability and the shape of the nuclei (n). (g) Pseudocolor coded confocal image of a AZ3 cell showing peripherally regionalized cytoplasm and loss in the nuclear (n) DNA-associated EB fluorescence. (h) Pseudocolor code image of a highly vacuolate dead cell of the AZ3 showing very weak EB fluorescence alloctated with the fragmented nuclei (n). 
that observed in abscission regions of other taxa (Sexton and Roberts, 1982). However, we were not able to detect the presence of any cluster of thick-walled cells in the abscission zone before or after induction either in the scanning electron microscope images or in semi-thin sections as observed by Ruscio et al. (1985). This discrepancy might be due to the differences in the age of the plants under investigation or the differences in the climate. However, the possible role of such a group of cells in the induction of abscission is still unclear.

The scanning images of the completely developed abscission zone reveal that the abscission layer is also formed across the vascular bundles leading in part to the separation of the vascular strands. Such a situation has so far not been reported in Prunus persica. Based on our data, it is not possible to determine the mechanism for rupture of xylem vessels. However, it seems logical to consider that it is similar to that observed in P. cerasus (Stösser et al.. 1969b), wherein the final separation is apparently achieved by mechanical fracturing.

The observed features of CTC fluorescence in the cells of the AZ3 indicate that it is mainly reporting $\mathrm{Ca}^{2+}$ distribution because: I) unlabeled cells hardly show any fluorescence beyond the background levels, 2) posttreatment of CTC-labeled sections with 5 mM EGTA (Tirlapur and Willemse, 1992; Wolniak et al., 1980) eliminates the fluorescence, 3) the CTC has higher affinity to $\mathrm{Ca}^{2+}$ in apolar enviromnents by a factor of 3 than that for $\mathrm{Mg}^{2+}$, and 4) CTC fluoresces in the cellular locations that contain high levels of free $\mathrm{Ca}^{2+}$ adjacent to hydrophobic sites, particularly membranes (Tsien, 1989). More recently, Timmers et al. (1991) used confocal laser scanning microscopy to demonstrate that distribution of $\mathrm{Ca}^{2+}$ visualized by Fluo-3 (a fluorescent indicator for free $\mathrm{Ca}^{2+}$ ) and that detected with CTC in plant cells arc identical.

Following the activation of the AZ3. we found an increase in the CTC fluorescence. which by implication reflects an increase in the level of membrane-associated $\mathrm{Ca}^{2+}$ of these cells. Such a transitory increase in $\mathrm{Ca}^{2+}$ in the cells of the abscission zone has also been reported during abscission in bean (Rasmussen and Bukovac, 1969). However, Stösser (1969) was unable to detect such an initial increase in ${ }^{45} \mathrm{Ca}$ in the cells of the abscission zone in $P$. cerasus. This might be due to the differences in the sampling procedure adopted (Stösser, 1969). Nevertheless, our finding of subsequent depletion of $\mathrm{Ca}^{2+}$ from the cells of the AZ3 concomitant with the process of cell separation are consistent with those of Stösser (1969) and Stösser et al. (1969a, 1969b) reported for cherries.

The observed transitory increase in $\mathrm{Ca}^{2+}$ in the cells of the AZ3 following embryoctomy could be linked to $\mathrm{C}^{2+}$-dependent activation of polygalacturonase (Pressey and Reger, 1989) implicated in degradation of cell walls (Rascio et al.. 1985). In fact, it has been demonstrated that, with the activation of the AZ3 zone, there is a significant increase in endocellulase and exopolygalacturonasce activity (Rascio et al., 1985). Moreover, the lysis of the middle lamella is observed throughout the abscission zone (Ruscio et al., 1985) during this period (i.e., 2 days after the treatment). It may well be that the initial increase in $\mathrm{Ca}^{2+}$ in the cells of the AZ3 is involved in activation of $\mathrm{Ca}^{2+}$-dependent nucleases involved in fragmentation of the nuclear DNA leading to death of these cells. This view is consistent with the gradual decrease in the size and morphology of the nucleus and also the loss of DNA. Interestingly, Nii et al. (1988) have demonstrated that. during senescence of leaves in $P$. persica, changes in the DNA content arc accompanied by changes in the levels of nuclease activity and that cell nucleus degradation is mediated by activation of a nuclease system as proposed in the present study.

These changes in nuclear morphology and loss of nuclear DNA arc analogous to the situation during apoptosis or programmed cell death seen in animal systems and that recently reported in Euglena gracilis (Tirlapur et al., 1992, 1993b). It is therefore conceivable that the death of abscising cells in peach is, in part, a physiological event for elimination of these cell types.

Our finding of high CTC fluorescence in the intercellular spaces is consistent with the suggestion (Stösser, 1969) that $\mathrm{Ca}$ from the cells of the abscission zone is lost. It was also proposed by Stösser et al. ( 1969) that there is a loss of $\mathrm{Ca}^{2+}$ from the cell walls, particularly that complexed with the pectic bridges. Thus, the major consequence of induction is the selective permeability of the membrane that results in leakage of ions as observed in senescing tissues (Ferguson, 1984; Ferguson and Drobak, 1988).

Using the modified antimonate precipitation technique (Poenie and Epel, 1987), we have recently observed unloading of cell-wallassociated $\mathrm{Ca}^{2+}$ into the intracellular spaces during later stages of cell separation (U.K. Tirlapur, unpublished data). Brady et al. (1985) investigated the interaction of the amount and molecular forms of polygalacturonase and $\mathrm{Ca}^{2+}$ in tomatoes and found that the differences in the digestion of the walls by polygalacturonase were dependent upon differences in $\mathrm{Ca}^{2+}$ content or the distribution of these ions. In a subsequent investigation, Bums and Pressey (1987) studied the $\mathrm{Ca}^{2+}$ content in the cell walls of ripening peaches and reported that the $\mathrm{Ca}^{2+}$ content remains constant in peach mesocarp. These authors suggested that pectin deesterification and wall softening during ripening may in part be factors that control the presence and amount of cell wall-middle lamella-associated $\mathrm{Ca}^{2+}$.

The observed initial increase in $\mathrm{Ca}^{2+}$ might be potentially involved in activation of calmodulin mediated senescence of the cells as observed in pea (Leshem et al., 1984). This view is consistent with our recent confocal imaging of immunocytochemically detected changes in calmodulin levels in the cells of AZ3 (U.K. Tirlapur, unpublished data).

It has been demonstrated that newly synthesized protein may play an important role during induction of abscission (Rascio et al., 1985; Sexton and Roberts, 1982; Stösser, 1971); hence, it seems quite unlikely that abscission is directly mediated by ubiquitin-like protein (Hershko and Ciechanover, 1992; Jentsch et al., 1990; Vierstra, 1987) that has hitherto been implicated in proteolysis in different cell types.

\section{Literature Cited}

Arnold, C.E.. L.C. Anderson., G.L. Thomas. and J.H. Aldrich. 1981. CGA- 15281 induced abscission zone formation in peach fruit. Proc. Florida State Hort. Soc. 94:367-369.

Bacon. J.P., C. Gonzalez, and C.J. Hutchison. 1991. Applications of confocal laser scanning microscopy. Trends Cell Biol. 1:172-175.

Brady. C.J.. W.B. McGlasson., J.A. Pearson.. S.K. Meldrum, and E. Kopeliovitch. 1985. Interactions between the amount and molecular forms of poly- galacturonase. calcium and firmness in tomato fruit. J. Amer. Soc. Hort. Sci. 110:254-258.

Bukovac. M.J. 1971 The nature and chemical promotion of abscission in maturing cherry fruit. HortScience 6:385-388.

Burns. J.K. and R. Pressey. 1987. $\mathrm{Ca}^{2+}$ in cell walls of ripening tomato and peach. J. Amer. Soc. Hort. Sci. 112:783-787.

Connors, C.H. 1919. Growth of fruits of the peach. N.J. Agr. Expt. Stat. Annu. Rpt. 40:82-88.

Daniell, J.W. and R.E. Wilkinson. 1972. Effect of ethephon induced ethylene on abscission of leaves and fruits of peaches. J. Amer. Soc. Hort. Sci. 97:682-685.

Dermen. H. and R.N. Stewart. 1973. Ontogenetic study of floral organs of peach (Prunus persica) utilizing chimeral plants. Amer. J. Bot. 60:283-291.

Ferguson, I.B. 1984. Calcium in plant senescence and fruit ripening. Plant Cell Environ. 77:477-489. 
Feguson, I.B. and B.K. Drobak. 1988. Calcium and the regulation of plant gowth and senescence. HortScience 23:262-266.

Hanson, J.B. 1983. The role of calcium in plant growth, p. 1-24. In: D.D. Randal, D.G. Blevins, and I.B. Ferguson (eds.). Current topics in plant biochemistry and physiology. vol. 1. Univ. of Missouri, Columbia.

Hershko. A. anti A. Ciechanover. 1992. The ubiquitin system for protein degradation. Annu. Rev. Biochem. 61:761-807.

Jentsch, S.W.. K. Ko, D. Milkowski, and H.A. Reins. 1990. Ubiquitinconjugation enzymes: Novel regulators of eukaryotic cells. Trend Biochem Sci. 15:195-198.

Jerie. P.H. 1976. The role of ethylene in abscission of cling peach fruit. Austral. J. Plant Physiol. 3:747-754.

Jones. R.G.W. and O.R. Lunt. 1967. The function of calcium in plants. Bot. Rev. 33:407-426.

Leshem. Y.Y., S. Sridhara. and J.E. Thompson. 1984. Involvement of calcium and calmodulin in membrane deterioration during senescence of pea foliage. Plant Physiol. 75:329-335.

Marinos, N.G. 1962. Studies on submicroscopic aspects of mineral deficiencies: I. Calcium deficiency in the shoot apex of barley. Amer. J. Bot. 30:834-841.

Martin. G.C. and C. Nishijima. 1972. Levels of endogenous growth regulators in abscising and persisting peach fruits. J. Amer. Soc. Hort. Sci. 97:561-565.

Nelson. J.B., C.E. Arnold.. J.H. Aldrich, and L.C. Anderson. 1984. Location of three fruit-related abscission zones in peach. J. Amer. Soc. Hort. Sci. 109:672-676.

Nii. N.. S. Kawano. S. Nakamura, and T. Kuroiwa. 1988. Changes in the fine structure of chloroplast DNA of peach leaves during senescence. J. Jpn. Soc. Hort. Sci. 57:390-398.

Osborne. D.J. 1979. Target cells new concepts for plant regulation in horticulture. Sci. Hort. 30: 1-13.

Paliyath. G., B.W. Poovaiah.. G.R. Munske, and J. Magnuson. 1984. Membrane fluidity in senescing apples: Effects of temperuture and calcium. Plant Cell Physiol. 25:1083-1087.

Poenie, M. and D. Epel. 1987. Ultrastructural localization of intracellular calcium stores by a new cytochemical method. J. Histochem. Cytochem. 35:939-956.

Poovaiah, B.W. 1988. Molecular and cellular aspects ofcalcium action in plants. HortScience 23:267-271.

Poovaiah, B.W. and A.C. Leopold. 1973. Deferral of leaf senescence with calcium. Plant Physiol. 52:236-239.

Poovaiah, B.W. and H.P. Rasmussen. 1973. Calcium distribution in the abscission zone of bean leaves. Plant Physiol. 52:683-684.

Pressey, R. and B.J. Reger. 1989. Polygalacturonase in pollen from corn and other grasses. Plant Sci. 59:57-63.

Rascio, N., G. Casadoro. A. Rumina. and A. Masia. 1985. Structural and biochemical aspects of peach fruit abscission (Prunus persica L.. Batsch). Planta 164:1-11.

Rasmussen. H.P. and M.B. Bukovac. 1969. A histochemical study of abscission layer formation in the bean. Amer. J. Bol. 56:69-76.
Schneider, G.W. 1977. Studies on the mechanism of fruit abscission in apple and peach. J. Amer. Soc. Hort. Sci. 102: 179-181.

Sexton. R. and J.A. Roberts. 1982. Cell biology ofabscission. Annu. Rev. Plant Physiol. 33:135-162.

Stösser, R. 1969. Histoautoradiographische lokalisierung von ${ }^{15} \mathrm{Calcium}$ in der Trennzone tier Früchte van Süß- und Saurerkirsche. Z. Pflanzenphysiol. 61:314-321.

Stösser, R. 1971. Localization of RNA and protein synthesis in the developing abscission layer in fruit of Prunus cerasus L. Z. Pflanzenphysiol. 64:328-334.

Stösser. R., H.P. Rasmussen. and M.J. Bukovac. 1969a. Histochemical changes in the developing abscission layer in fruits of Prunus cerasus L. Planta 86:151-164.

Stösser, R., H.P. Rasmussen, and M.J. Bukovac. 1969b. A histological study of abscission layer formation in cherry fruits during maturation. J. Amer. Soc. Hort. Sci. 94:239-243.

Timmers. A.C.J.. H.D. Reiss, and J.H.N. Schel. 1991. Digitonin-aided loading of Fluo-3 into embryogenic plant cells. Cell Calcium 12:515521.

Tirlapur, U.K. and M. Cresti. 1992. Computer-assisted video image analysis of spatial variations in membrane-associated $\mathrm{Ca}^{2+}$ and calmodulin during pollen hydration. germination and tip growth in Nicotiana tabacum L. Ann. Bot. 69:503-508.

Tirlapur, U.K., D.-P. Häder, and R. Scheuerlein. 1992. UV-B mediated damage in the photosynthetic flagellate Euglena gracilis. studied by image analysis. Beitr. Biol. Pflanzen. 61:305-317

Tirlapur, U.K., M. Scali., A. Moscatelli., C. Del Casino., G. Cai., A. Tiezzi, and M. Cresti. 1994b. Confocal imagc analysis of spatial varialions in immune-cytochemically identified calmodulin during pollen hydration. germination and pollen tube tip growth in Nicotiana tabacum L. Zygote. 2:63-69

Tirlapur, U.K., S. Tremel., D.-P. Häder, and R.W. Scheuerlein. 1993c. UV-B mediated DNA fragmentation in Euglena gracilis is mediated by an influx of $\mathrm{Ca}^{2+}$ and activation of a $\mathrm{Ca}^{2+}$-dependent endonuclease. Eur. J. Cell Biol. Suppl. 37 (vol. 60):94.

Tirlapur, U.K.. J.L. Van Went, and M. Cresti. 1993a. Visualization of membrane calcium and calmodulin in embryo sacs in situ and isolated from Petunia hybrida L. and Nicotiana tabacum L. Ann. Bol. 71:161167.

Tirlapur, U.K. and M.T.M. Willemse. 1992. Changes in calcium and calmodulin levels during microsporogenesis, pollen development and germination in Gasteria verrucosa (Mill.) H. Duval. Sex. Plant Reprod. $5: 214-223$.

Tsien, R.Y. 1989. Fluorescent indicators of ion concentrations. Methods Cell Biol. 30:127-156.

Vierstra. R.D. 1987. Ubiquitin, a key component in the degradation of plant proteins. Physiol. Plant. 70:103-106.

Wolniak, S.M., P.K. Hepler, and W.T. Jackson. 1980. Detection of membrane calcium distribution during mitosis in Hemanthus endosperm with chlorotetracycline. J. Cell Biol. 87:23-32. 